\title{
Politeness Strategies of Minangkabau Speakers in Criticizing Based On Their Educational Level
}

\author{
Fauziah Rahmi, Ermanto, Harris Effendi Thahar \\ Universitas Negeri Padang, Indonesia \\ fauziarahmi79@gmail.com
}

\begin{abstract}
The aims of the study were (1) to describe the strategies of critically speaking criticism of Minangkabau speakers in West Sumatra based on their educational level and (2) to describe the level of use of Brown and Levinson-based strategies in a speech criticizing the Minangkabau speakers in West Sumatra based on their educational level. This type of research was qualitative with descriptive method. Data collection technique in this study was a questionnaire. The results of this study was: (1) a speech strategy that was widely used in speech acts criticizing the Minangkabau speakers in West Sumatra according to the level of education is S3 (TBKN); S2 (TBKP); S1 (TTB); DIII (TBKP and TBKN); SMA (TBKP); (2) TTB, (3) TBKN, (4) SS, and SMP (TTB), and (2) the level of use of Brown and Levinson-based strategies in speech criticizing the Minangkabau speakers in West Sumatra based on their educational level were (1) TBKP, and $B D H$.
\end{abstract}

Keywords-speech acts; criticize; expressive

\section{INTRODUCTION}

Language politeness is a term related to manners, respect, and decency. The politeness aims to build good communication by avoiding ineffective communication (Budiwati, 2017; Astuti \& Wahyudi, 2017; Maulidi, 2015; Alviah, 2014; Gunawan, 2013). Therefore, in the language, it is very important to pay attention to the situation and condition of communication in order to precisely choose the vocabulary used in the language interaction (Budiwati, 2017; Yanto, 2017; Ismail dan Hassan, 2016; Nurjamily, 2015).

In the social interaction of speakers and speakers have expectations related to the good name, namely the desire to be respected. When a speaker expresses something that pose a threat to the expectations of his good name, this is called a threatening act. Conversely, if the speaker can avoid the possibility of face-threatening action then it is called a face-saving action, Yule (2006, p. 105). Furthermore, Yule divided her face into two, positive and negative faces. First, the negative face is the need for independence, freedom of action, and not being depressed by others. The word 'negative' here does not mean 'bad'; This negative word is just the opposite of 'positive'. Second, a positive face is the need to be accepted by others. The simple term, a negative face is a need for independence, while the positive face is the need to be contacted.

The act of speech that has the potential to bring down the face of speech actor is expressive speech. Expressive utterances are defined as evaluations of a thing mentioned in the utterance. This form of expressive speech is one of the criticisms (Wulandari, 2015). Criticism can influence interpersonal relationships between actors to cause conflict, (Mey in Don and Ahmad, 2013). This act of speech relies heavily on situations where the speaker must know how to act criticized. Speakers must consider such aspects as the listener, the relationship with the listener, the appropriate topic, purpose, and linguistic form used (Farnia, 2015). In relation to the criticism, in order to avoid face-threatening action, Brown and Levinson (1987, p. 60) describe five strategies that can be used in communication, namely: (1) speaking frankly or bald on record; (2) speak by using positively modesty politeness; (3) speak using negative politeness; (4) speak vaguely (off record). (5) does not say something or speak in the heart.

Research on language politeness has been done by many other researchers. Budiawati (2017) has conducted research on language politeness. The object of his research is the linguistic politeness of students in interacting with lecturers in WhatsApp (WA) social media and Line Chat at Ahmad Dahlan University. Budiawati found out of 35 student and lecture data in Social media WhatsApp (WA) and Line Chat is known to have complained and deviated to some maxims, such as maxim of wisdom, maxim of generosity, maxim of acceptance, maxim of consent, and maxim of sympathy; and there are functions of language politeness, such as representative function, directive function, expressive function, and commissive function.

The next researcher is Nurjamily (2015). The object of research researched Nurjamily is language courtesy in a family environment. Nurjamily found that the family used a negative politeness strategy developed by Brown and Levinson and the politeness principles developed by Leech. However, these principles are not always used in conversations in the family environment that they examine.

In contrast to the research that has been done by Budiawati and Nurjamily, this research is more specific, ie focusing on the politeness of speech acts criticize. This research is done on the act of criticized speech because criticized is often a 
problem in communicating. When a speaker wants to criticize someone he is afraid his partner will be offended by his words. Therefore, speakers need to consider appropriate strategies of use. In addition, this research is also done because of seeing the phenomenon, especially in Minangkabau, West Sumatra which current students, students or the community no longer pay attention to language politeness. Whereas in Minangkabau has been arranged how to tell, both to older people, younger, age, and people who are respected, this is known as Kato nan ampek (kato mandaki, malereng, mandata, manurun). Those things is suitable with the view of Kusno (2014) said that in present the values of politeness in social life are not considered anymore. Based on the phenomenon that occurs, the question arises whether the Minangkabau speakers in West Sumatra courteous when doing speech acts criticize?

The scope of research conducted by Budiawati and Nurjamily is not sufficiently wide so the results of this study only show how politeness speaks in a small scope. The research is also still general, so the results of their research have not answered what communication strategy used to speak politely?

Based on the description of the problem above the objectives of this study are (1) to explain the strategies of speakers criticizing the Minangkabau speakers in West Sumatra based on their educational level and (2) to explain the level of use of the Brown and Levinson-based strategies in speech criticizing the Minangkabau speakers in Sumatra West based on education level.

\section{METHODS}

This research type was qualitative research with descriptive method. This research belongs to qualitative research because it aims to produce descriptive data in the form of speech acts criticized by polite Minangkabau speakers in West Sumatra based on education level. The research data of this study was in the form of sentences that have been written by 100 respondents on the questionnaire given. Data collection technique in this study was a questionnaire.

The instrument of this research was the researcher herself. The reason why the researcher used herself as a research instrument was based on the belief that only human beings are able to reach and assess the meaning of an event or various social interactions, Moleong $(2009$, p. 8$)$. To carry out this research, researcher conducted data analysis. As said Moleong (2009, p. 168), the position of researcher in qualitative research is as a planning, implementation of data collection, analysis of data interpretation, and eventually become the pioneer of research results.

Data were collected by asking respondents to fill out questionnaires about criticized speech acts that researcher has made. Data analysis technique based on the following stages. First, the questionnaire was distributed to a hundred respondents of Minangkabau speakers in West Sumatra with different levels of education. Second, the respondents read the instruction of filling methods that exist in the questionnaire that has been given. Thirdly, the respondents made their identity. Fourth, respondents wrote sentences that was used in speech acts criticizing questionnaire sheet. Fifth, data were collected and inventoried. Sixth, the data was recorded based on the respondents education level. Seventh, the data was analyzed systematically based on the research objectives. The analysis was done by referring to the theory of the strategy presented by Brown and Levinson (1987, p. 69), namely: (a) speak frankly or without further ado (TTB); (b) speak using positively modesty courtesy (TBKP); (c) speak with negative courtesy grants (TBKN; (d) speak vaguely (SS); and (e) not tell something or speak in the heart (BDH).

\section{FINDING AND DISCUSSION}

\section{The strategy to speak critically Minangkabau speakers in West Sumatra based on the level of education}

Talks about strategies to criticize Minangkabau speakers in West Sumatra will be seen based on sentences that have been written by respondents on the questionnaire. Then, the sentence is analyzed based on the type of strategy tells Brown and Levinson. The analysis was carried out to find out the widely spoken strategies used in criticizing Minangkabau speakers in West Sumatra based on their educational level. This level of education is classified at the level of Junior High School, Senior High School (SMA), Bachelor (DIII), Bachelor (S1), Master (S2), and Doctorate (S3). The research findings on the strategy of criticizing the Minangkabau speakers in West Sumatra based on their level of education can be seen in the following table. 
Table 1

Speaking Strategy Criticizing Minangkabau Speakers in West Sumatra based on Education Level

\begin{tabular}{ccccccc}
\hline \multirow{2}{*}{$\begin{array}{c}\text { Speaking } \\
\text { Strategy }\end{array}$} & \multicolumn{6}{c}{ Level of Education } \\
\cline { 2 - 7 } S3 & S2 & S1 & DIII & SMA & SMP \\
\hline TBKP & 1 & 1,4 & 1 & $1,2,4$ & $1,2,4$ & 2,4 \\
\hline TBKN & $2,3,4$ & \multicolumn{5}{c}{$1,3,4$} \\
\hline TTB & 3 & 3 & $2,3,4$ & 2,3 & 2,3 & $1,2,3$ \\
\hline SS & & 2 & & & & \\
\hline DBH & & & 1 & & \\
\hline
\end{tabular}

Information

1. criticize an elder or a higher person

2. criticize the same or equal person

3. criticize a younger or lower person

4. criticize a respected person

Speech strategies that are often used in speech acts criticize the Minangkabau speakers in the Indonesian language at the level of doctoral education as follows. First, speech acts criticize politely an older or higher person and not yet familiar is to speak with positive courtesy pretenses (TBKP). Second, speech acts politely criticize people who are equal or equal and not yet familiar are using negative courtesy modes (TBKN). Thirdly, speech acts criticize the polite, younger or lower-level person and not yet familiar with using TTB and TBKN because the percentage of use rate are both the same. The fourth criticized polite respected person is spoken by using negative courtesy nonsense (TBKN).

Speechy strategies that are often used at the Masters level as follows. First, speech acts criticize politely an older or higher person and not yet familiar is to speak with positive courtesy pretenses (TBKP). Second, speech acts politely criticize people who are equal or equal and not familiar are vaguely spoken (SS). Thirdly, speech acts criticized in a polite manner a person who is younger or inferior to his position and not yet familiar is spoken straightly without further ado (TTB). Fourth, polite criticism of a respected person is spoken by using positively courtesy ciphers (TBKP).

Speech strategies that are often used at the level of undergraduate education as follows. First, speech acts criticize politely an older or higher person and not yet familiar is to speak with positive courtesy pretenses (TBKP). Second, speech acts criticize the polite person of equal or equal position and not yet familiar is told frankly without further ado (TTB). Thirdly, speech acts criticized in a polite manner a person who is younger or inferior to his position and not yet familiar is spoken straightly without further ado (TTB). Fourth, the polite criticism of a respected person is to speak frankly without further ado (TTB).

Speechy strategies that are often used at the level of Undergraduate education as follows. First, speech acts criticize polite people who are older or taller and not yet familiar are using TBKP, TBKN, and BDH because the percentage rate of use of all three is the same. Secondly, speech acts criticize polite people equal or equal and not familiar is using TTB and TBKP because of the percentage of the level of use of both the same. Thirdly, speech acts criticize the polite, younger or lower-level person and not yet familiar with using TTB and TBKN because the percentage of use rate are both the same. Fourth, polite criticize the respected people is to use TBKP and TBKN because of the percentage of the use of both levels the same.

Speechy strategies that are often used at the level of senior high school education as follows. First, the act of speech criticizes politely an elder or higher person and is not yet familiar with the use of positively modesty courtesy (TBKP). Second, speech acts criticize polite people equal or equal and not familiar is to use TTB and TBKP speak as the percentage of the use of both levels the same. Thirdly, speech acts criticized in a polite manner a person who is younger or inferior to his position and not yet familiar is spoken straightly without further ado (TTB). Fourth, polite criticism of a respected person is spoken by using positively courtesy ciphers (TBKP).

Speech strategies that are often used at the level of secondary school education as follows. First, the act of speech criticized politely an elder or taller person and not yet familiar is to speak frankly without further ado (TTB). Secondly, speech acts criticize polite people who are equal or equal and not yet familiar are using TTB and TBKP because the percentage of their use level is the same. Thirdly, speech acts criticized in a polite manner a person who is younger or inferior to his position and not yet familiar is spoken straightly without further ado (TTB). Fourth, polite criticism of a respected person is spoken by using positively courtesy ciphers (TBKP). 
Levels of use of the strategies speak of Brown and Levinson in speech criticize the Minangkabau speakers kindly in West Sumatra based on the level of education

In this study, the strategies speak of Brown and Levinson will be seen from the level of its use. It is based on 100 of respondents when doing speech acts criticize. The findings of research on the level of weariness of the strategy speak of Brown and Levinson when doing speeches criticize the Minangkabau speakers kindly in West Sumatra based on the level of education.

Table 2

Level of Use of Strategy Speaking Brown and Levinson in Speech Criticizing Minangkabau Speakers in West Sumatra by Level of Education

\begin{tabular}{ccccccccc}
\hline \multirow{2}{*}{$\begin{array}{c}\text { Strategy } \\
\text { Speak }\end{array}$} & \multicolumn{9}{c}{ Level of Education } & & Amount & Ranking \\
\cline { 2 - 8 } & S3 & S2 & S1 & DIII & SMA & SMP & & \\
\hline TBKP & 1 & 2 & 1 & 3 & 3 & 2 & 16 & 1 \\
\hline TBKN & 3 & & & 3 & & & 7 & 3 \\
\hline TTB & 1 & 1 & 3 & 2 & 2 & 3 & 12 & 2 \\
\hline SS & & 1 & & & & & 1 & 4 \\
\hline DBH & & & & 1 & & & 1 & 4 \\
\hline
\end{tabular}

Table 2 shows the level of use of strategies according to Brown and Levinson in speech acts criticizing the Minangkabau speakers well according to the level of education is (1) to speak by using positively modest politeness; (2) speak frankly or without preamble (bald on record); (3) speak using negative politeness; and (4) speak vaguely (off record) and not tell something or speak in the heart.

Thus, it can be concluded that the criticism-speaking strategy most often used by Minangkabau speakers is the strategy of speaking politeness positive (positive politeness). strategies that show positive politeness according to Brown and Levinson (1987, p. 103-129) are 15, namely: 1) taking note of the preferences, desires, and needs of speakers, 2) giving attention, approval, and sympathy to the speakers; 3) intensifying the speaker's attention with the event or fact, 4) using group identity markers (greetings, dialects, jargon or slang), 5) seeking approval on common topics or repeating part / all speech, 6) avoiding disagreement with false approval, false approval, cheating for good , fencing opinion, 7) showing things that are deemed to have similarities through preamble and presuppositions, 8) using jokes, 9) expressing the understanding of the speaker's intentions, 10) giving bids or promises, 11) showing optimism, 12) engaging speakers and speakers in the activity, 13) give questions or ask for reasons, 14) declare relationships on a reciprocal basis, and 15) give gifts (goods, sim starch, attention, cooperation) to the speakers.

The use of the positive courtesy strategies found in the research can be seen in the following examples:

(1) Maaf Pak, akan lebih baik jika rokoknya dimatikan karena ada ibu hamil yang duduk di sebelah". Konteks: seorang mahasiswa mengkritik seorang bapak yang merokok di dalam bus. (R-07)

Sorry Sir, it is better for you to put out you cigarette because there is a pregnant mother beside you". Contexts: A student critics a man that smoke inside bus

(2) Đek, agar tidak menganggu mahasiswa lain yang sedang ujian, bagaimana jika volume musiknya dikecilkan?" Konteks: mahasiswa sedang melaksanakan ujian akhir semester di kampus tetapi ada sebagian mahasiswa yang memutar musik dengan volume yang keras. (R-23)

Hey/Sist, to not bother others students in their examination, can you lessen the volume? Contexts: students is on a last semester test in class but there are some students play a loud music.

(3) “Ukhti, sebaiknya kita membuang sampah ditempat sampah". Konteks: seorang senior melihat juniornya yang membuang sampah di sembarangan tempat. (R-84)

Sist, it is better for us to throw the garbage in a trash can. Contexts: a senior see a junior that throw garbage in carelessly place. 
(4) Maaf sebelumnya Bu, selaku pimpinan alangkah baiknya jika ibu dapat menjalin hubungan baik dengan karyawan kantor ibu". Konteks: Saat seorang kolega perusahaan datang dan melihat salah satu pimpinan perusahaan itu tidak menjawab sapaan dari karyawannya. (R-91)

Sorry mam, as a director, it is better for you to intertwine a good relationship with your subordinates.

Contexts: a colleague see that a director does not respond the greeting from her subordinate

In example (1) shows that the student as the speaker uses the word hello Pak/Sir when talking to the speaker who is older than the speaker. In addition, the sentence he used to criticize is in the form of suggestions along with the reasons that support the meaning of his speech. This is seen in phrases akan lebih baik jika/it is better if.. (suggestions) and word usage karena (reason). In the example, the speaker uses a positive courtesy-style strategy developed by Brown and Levinson in the use of the word greeting and gives a statement of reason.

In the example (2) sentence "Bagaimana jika volume musiknya dikecilkan?"/ Can you leseen the volume? is a question sentence that in telling a sister class to his class sister as a form of criticism against what he did. The question form used is one of the positive courtesy-speak strategies aimed at getting the speaker's approval so that he will do what the speaker means in his speech. Speakers also use the word hello Dek in his speech.

In Example (3) it shows that the speaker criticizes his or her partner by including himself in the speech by using the phrase sebaiknya kita. In addition, the sentence also uses the word hello Ukhti. Thus, Brown's and Levinson's positive courtesy strategy that he uses is to engage the speaker in the actions intended in his speech and use the greeting.

In example (4) the phrase selaku pimpinan alangkah baiknya/ as a director it is better indicates that the speaker uses reciprocal relations in his critical sentence. The sentence also uses a positive courtesy strategy of Brown and Levinson's greeting form $\mathbf{B u}$ which is the identity marker.

An example is a form of criticism used by the Minangkabau people. When viewed from the example, in knowing that each of the speech has a different context. The different contexts are 1) speech acts criticizing politely an elder or higher person and not yet familiar; 2) speech acts politely criticized people of equal or equal status and not yet familiar; 3) speech acts criticize the polite person or his inferior and unfamiliar position; and 4) politely criticize the respected person. Thus, it can be concluded that Brown's and Levinson's positive politeness strategies employed by Minangkabau speakers in polite criticism include using the greeting, using a question sentence as a form of approval, using group identity markers, involving speakers in the activities mentioned in the speeches, expressing mutual relationships, and states the reasons.

\section{CONCLUSION}

Based on these findings can be concluded as the following. First, the narrative strategy that is widely used in speech acts critically criticized Minangkabau speakers in West Sumatra based on their educational level: S3 (TBKN); S2 (TBKP); S1 (TTB); DIII (TBKP and TBKN); SMA (TBKP); and SMP (TTB). Thus the most widely spoken strategy is the story-based strategy using positively modified politeness. Second, the level of use of the strategy of Brown and Levinson in speech acts criticizing Minangkabau speakers in West Sumatra based on his education level are (1) TBKP, (2) TTB, (3) TBKN, (4) SS and BDH.

Well, mannered in language is one of the supporting factors for the establishment of good communication. For that, a speaker and a speaker should be wise to use the strategy of telling. It is hoped that speakers can choose the exact strategies to be used in a communication process. Choosing the right telling strategy can be done taking into account the non-linguistic context during which the communication takes place. If this is done then the speakers can minimize the facial threat faces said.

\section{References}

Alviah, I. (2014). Kesantunan berbahasa dalam tuturan novel Para Priyayi karya Umar Kayam.” Jurnal Seloka: Pendidikan Bahasa dan Sastra Indonesia, 3 (2), 128-135.

Astuti, T \& Wahyudi, T. (2017). Kesantunan berbahasa dalam Surat Kabar Linggau Pos.” Jurnal Kajian Bahasa, Sastra dan Pengajaran (KIBASP), 1(1), 130-146.

Budiawati, T. R. (2017). Kesantunan berbahasa mahasiswa dalam berinteraksi dengan dosen di Universitas Ahmad Dahlan: analisis pragmatik". URECOL PROCEEDING UAD, ISBN 978-979-3812-42-7, 557—571.

Brown, P. \& Levinson, S.C. (1987). Politeness some universals in language usage. New York: Cambridge University Press.

Don, Z. M. \& Ahmad, I. (2013). Interactionally achieving face in criticism-criticism response exchanges.” Journal language \& communication, 5(3), 221-231.

Farnia, M. (2015). A sociopragmatic analysis of the speech act of criticism by Persian native speakers. International" Journal of humanities and cultural studies, 2 (3), 305-327. 
Gunawan, F. (2013). Wujud kesantunan berbahasa mahasiswa terhadap dosen di STAIN Kendari: kajian sosiopragmatik". Journal Arbitrer, 1(1), 8-18.

Ismail, M. L. H. \& Hassan, A. F. M. (2016). Kesantunan berbahasa dalam kalangan pelajar Universiti Utara Malaysia (Uum). Proceeding of ICECRS ISSN. 2548-6160, 959-966.

Kusno, A. (2014). Kesantunan bertutur oleh orang tua kepada anak di lingkungan rumah tangga." Jurnal Dinamika Ilmu, 14(1), 13-26.

Maulidi, A. (2015). Kesantunan berbahasa pada media jejaring sosial facebook." Jurnal Bahasantodea, 3(4), 42 —49.

Moleong, Lexy J. (2009). Metode penelitian kualitatif. Bandung: Remaja Rosdakarya.

Nurjamily, W. O. (2015). Kesantunan berbahasa Indonesia dalam lingkungan keluarga: kajian sosiopragmatik". Jurnal Humanika, 3 (15).

Wulandari, et al., (2015). Tindak tutur ekspresif Mario Teguh dalam acara Golden Ways". Jurnal Bahasa, Sastra dan Pembelajaran, 2(1), 99-113.

Yanto, Y. (2017). Kesantunan berbahasa dalam komunikasi terapeutik perawat di RSUD Dr. Wahidin Sudiro Husodo Mojokerto:kajian pragmatik." Jurnal Skriptorium, 2(2), 135-145.

Yule, G. (2006). Pragmatik. (Diterjemahkan oleh Indah Fajar Wahyuni). Yogjakarta: Pustaka Pelajar. 